Discussion Paper No. 10-045

\title{
Why Do Financial Market Experts Misperceive Future Monetary Policy Decisions?
}

Sandra Schmidt and Dieter Nautz

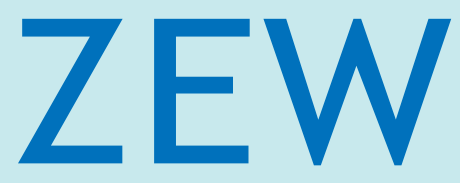

Zentrum für Europäische Wirtschaftsforschung $\mathrm{GmbH}$

Centre for European

Economic Research 
Discussion Paper No. 10-045

\title{
Why Do Financial Market Experts Misperceive Future Monetary Policy Decisions?
}

\author{
Sandra Schmidt and Dieter Nautz
}

Download this ZEW Discussion Paper from our ftp server:

ftp://ftp.zew.de/pub/zew-docs/dp/dp10045.pdf

Die Discussion Papers dienen einer möglichst schnellen Verbreitung von neueren Forschungsarbeiten des ZEW. Die Beiträge liegen in alleiniger Verantwortung der Autoren und stellen nicht notwendigerweise die Meinung des ZEW dar.

Discussion Papers are intended to make results of ZEW research promptly available to other economists in order to encourage discussion and suggestions for revisions. The authors are solely responsible for the contents which do not necessarily represent the opinion of the ZEW. 


\section{Non-Technical Summary}

Central bank communication is increasingly important to both central banks and financial market participants. Effective communication should ensure that financial markets understand the central bank's interest rate policy. However, central bank communication is not always effective and interest rate forecast errors can occur for two reasons. First, forecasters may understand monetary policy but misperceive future interest rate decisions simply because they are wrong about future inflation and output. Second, the forecasters may fail to understand monetary policy and the interest rate rule applied by the central bank.

This paper aims to shed more light on communication by the European Central Bank (ECB), disagreement among financial experts over future interest rate decisions, and the sources of policy misperception. To this end, we use survey data on expected interest rates, inflation and output growth from the Financial Market Survey collected by the Centre for European Economic Research. We assume that the ECB sets the interest rates according to a Taylor rule and that the surveyed financial market experts base their interest rate forecasts on a Taylor rule likewise. In the following, we form interest rate forecast errors and decompose them according to a Taylor-rule-type model. Consequently, we can infer whether the financial market experts correctly perceive the ECB reaction function.

The empirical findings show that the financial market experts systematically misperceive the ECB's Taylor rule parameters. More precisely, their estimate of the inflation parameter is higher than the ECB's inflation parameter but becomes more accurate after an ECB clarification about its monetary policy strategy in May 2003. The estimation results further suggest that the disagreement among experts about the ECB's reaction to inflation has not increased since the financial market crisis. 


\section{Zusammenfassung}

Kommunikation von Zentralbanken gewinnt für Zentralbanken selbst wie auch für Akteure an Finanzmärkten an Bedeutung. Eine effektive Kommunikation soll sicher stellen, dass die Finanzmärkte die Zinspolitik der Zentralbanken verstehen. Dennoch sind Zinsprognosen nicht immer korrekt; Prognosefehler haben im Wesentlichen zwei Ursachen. Erstens kann es sein, dass Finanzmarktteilnehmer zwar die geldpolitische Strategie verstehen, jedoch künftige Zinsentscheidungen falsch voraussagen, da sie falsche Annahmen über Inflation und Wachstum treffen. Zweitens kann es sein, dass Finanzmarktexperten die von der Zentralbank angewendete Zinsregel nicht kennen.

Diese Arbeit untersucht die Kommunikationspolitik der Europäischen Zentralbank (EZB), die Uneinigkeit unter Finanzmarktexperten hinsichtlich künftiger Zinsentscheidungen und die Ursachen unzutreffender Zinsprognosen. Hierzu verwenden wir Umfragedaten zu erwarteten Zinsen, Inflation und Konjunktur, die im Rahmen des Finanzmarkttests vom Zentrum für Europäische Wirtschaftsforschung erhoben werden. Wir nehmen an, dass die EZB die Zinsen entsprechend einer Taylorregel setzt und dass die befragten Experten ihre Zinsprognosen ebenfalls auf Grundlage einer Taylorregel bilden. Im Weiteren bilden wir Zinsprognosefehler und schlüsseln sie entsprechend der Taylorregel von Zentralbank und Experte auf. Daraus schlussfolgern wir, ob die Umfrageteilnehmer die Taylorregel der EZB korrekt wahrnehmen.

Die Ergebnisse zeigen, dass die Finanzmarktexperten die Taylorregel der EZB nicht korrekt einschätzen. Sie geben dem Inflationsparameter ein größeres Gewicht als die EZB. Seit einer Kommunikation der EZB im März 2003, die die geldpolitische Strategie klarer dargelegt hat, können die Finanzmarktexperten die Reaktion der EZB auf Inflation besser einschätzen. Die Schätzergebnisse legen außerdem nahe, dass die Uneinigkeit der befragten Experten über die Reaktion der EZB auf Inflationsrisiken seit dem Ausbruch der Finanzkrise nicht zugenommen hat. 


\title{
Why Do Financial Market Experts Misperceive Future Monetary Policy Decisions?
}

\author{
Sandra Schmidt \\ Centre for European \\ Economic Research
}

\author{
Dieter Nautz* \\ Free University Berlin
}

July 6, 2010

\begin{abstract}
This paper investigates why financial market experts misperceive the interest rate policy of the European Central Bank (ECB). Assuming a Taylor-rule-type reaction function of the ECB, we use qualitative survey data on expectations about the future interest rate, inflation, and output to discover the sources of individual interest rate forecast errors. Based on a panel random coefficient model, we show that financial experts have systematically misperceived the ECB's interest rate rule. However, although experts tend to overestimate the impact of inflation on future interest rates, perceptions of monetary policy have become more accurate since clarification of the ECB's monetary policy strategy in May 2003. We find that this improved communication has reduced disagreement over the ECB's response to expected inflation during the financial crisis.
\end{abstract}

Keywords: Central bank communication, Interest rate forecasts, Survey expectations, Panel random coefficient model

JEL classification: E47, E52, E58, C23

\footnotetext{
*E-mail: s.schmidt@zew.de, dieter.nautz@fu-berlin.de. Support by the Deutsche Forschungsgemeinschaft (DFG) through CRC 649 "Economic Risk" is gratefully acknowledged. We thank Michael Ehrmann, Frieder Mokinski, Andreas Schrimpf, Michael Schröder, and seminar participants at the Centre for European Economic Research and the Study Center Gerzensee for helpful comments and suggestions. Andreas Klösel provided valuable research assistance.
} 


\section{Introduction}

Central bank communication is increasingly important to both central banks and financial market participants, see Blinder, Ehrmann, Fratzscher, DeHaan, and Jansen (2008). Effective communication should ensure that financial markets understand the central bank's interest rate policy, i.e., how interest rate decisions are linked to future inflation and output. However, central bank communication is not always effective and interest rate forecast errors can, and do, occur for two reasons. First, forecasters may indeed understand monetary policy but misperceive future interest rate decisions simply because they are wrong about future inflation and output. Second, the forecasters actually do not understand monetary policy and the interest rate rule applied by the central bank. In this case, communication should be improved because markets will misperceive interest rate decisions even under perfect information about the economic outlook. This paper employs survey data on financial market expectations about future interest rates, inflation, and output in the Euro area to shed more light on communication by the European Central Bank (ECB), disagreement among financial experts over future interest rate decisions, and the sources of policy misperception.

Our analysis employs individual interest rate forecasts by financial market experts taken from the Financial Market Survey conducted by the Centre for European Economic Research (ZEW). This is a monthly survey and comprises a rich set of qualitative expectations as to short-term interest rates, inflation, and output. Assuming that experts use Taylor-rule-type forecast equations for short-term interest rates, we explore whether interest rate forecast errors are driven by uncertainty about the future course of inflation and output or whether experts are confused about monetary policy rules. In particular, we assess the consequences of a major change in ECB communication that occurred in May 2003, at which time the ECB provided a more precise definition of price stability (inflation should be below but close to $2 \%$ ) and 
deemphasized the role of monetary aggregates for short-term policy decisions. Since then, the ECB's monetary analysis puts more emphasis on the long-term relationship between money supply and inflation. We also investigate whether the market's understanding of monetary policy has been affected by the recent economic crisis.

A great deal of research confirms the predictive content of survey data for macroeconomic variables, see e.g. Mitchell and Pearce (2007) and Dreger and Stadtmann (2008), who study the forecasting performance of the Wall Street Journal's panel of economists. Nolte and Pohlmeier (2007) find that economic indicators derived from the ZEW survey give good quality forecasts. Thus, survey data on expectations are increasingly used in the literature to evaluate central bank communication. For example, Capistrán and Ramos-Francia (2010) and Ehrmann, Eijffinger, and Fratzscher (2010) explore how the introduction of inflation targeting affects the dispersion of inflation expectations in surveys. Lange, Sack, and Whitesell (2003), Swanson (2006), Ehrmann and Fratzscher (2007), and Sturm and de Haan (2009) show that more transparent communication generally improves market participants' predictions of the central bank's interest rate decisions.

All these contributions focus on the size and other statistical properties of individual forecast errors; no attempt is made to explain why interest rate forecast errors are made. Work by Berger, Ehrmann, and Fratzscher (2009) is closest in spirit to the approach we undertake here. These authors investigate the role of geography, i.e., the forecaster's location, in interest rate forecast error. By estimating Taylor-rule-type relationships for each forecaster separately, they decompose forecast errors as being either systematic or unsystematic. We extend Berger, Ehrmann, and Fratzscher (2009) in that our analysis of financial market experts' interest rate forecast errors includes information from the individual forecasts about inflation and output. Moreover, because we estimate a panel random coefficient model that allows for a dispersion of the estimated coefficients, our empirical approach can estimate the disagreement be- 
tween financial experts over monetary policy strategy, see Swamy (1970) and Rangvid, Schmeling, and Schrimpf (2009).

Our empirical results confirm that both the ECB and financial market experts use inflation as a Taylor rule argument. However, financial experts tend to overestimate the ECB's interest rate reaction to inflation. The ECB's attempt to clarify its monetary policy strategy in 2003 actually improved communication regarding the role of inflation. However, disagreement among experts about the central bank's reaction to output growth has increased since the beginning of the financial crisis, suggesting that financial market experts have difficulty assessing the ECB's strategy with respect to output fluctuations.

The paper is structured as follows. Section 2 introduces the ZEW financial market survey data and briefly discusses how recent work has used the aggregate survey balance statistics versus the individual survey expectations. Section 3 derives and decomposes interest rate forecast errors from a standard Taylor rule. Section 4 presents the econometric model, Section 5 sets out the empirical results on misperception of the ECB interest rate policy; Section 6 concludes.

\section{Survey Data on Expectations}

\subsection{The ZEW Financial Market Survey}

\subsubsection{The Data Set}

Since December 1991, the ZEW has been asking approximately 350 financial sector professionals about their expectations regarding a large set of macroeconomic variables, such as inflation, output, and interest rates. These professionals, or "financial market experts," usually have an academic background in economics and are also engaged in observing economic developments so they should be highly qualified for forecasting economic developments. Most of them work at banks $(60 \%)$; the rest are 
employed by the insurance industry (10\%), financial departments of industrial companies $(11 \%)$, or by other financial service providers. A majority (88\%) of these financial market experts are employed in Germany, $10 \%$ are located within the European region, and $2 \%$ are from non-European countries.

Usually during the first two weeks of a month, the financial market experts are asked whether they expect short-term interest rates to decrease $(-1)$, stay constant $(0)$, or to increase (1) within the next six months. The experts are asked for their predictions of the three-month interbank rate, i.e., the three-month Euribor in the Euro zone. Other questions asked that are relevant to this study have to do with changes in the annual inflation rate and the economic situation in the Euro zone. We approximate them by the six-month change in HICP inflation and by the six-month growth rate of industrial production, respectively. We prefer industrial production to GDP data because the former are available monthly, whereas the latter are available only quarterly. Table 4 in the Appendix provides descriptive statistics, Table 5 the detailed survey questions, and Figure 1 in the Appendix is a graphical illustration of the HICP inflation rate and the six-month growth rate of industrial production. The ZEW publishes aggregate balance statistics, defined as the difference between the relative share of answers falling into the categories "increase" and "decrease." In contrast, our analysis uses the individual, qualitative assessments of the experts. Of the 350 experts questioned each month, on average, about 300 answer. Thus, we base the estimation on an unbalanced panel of around 300 observations each month. For a sample period from January 2000 to March 2009, this gives us 32,072 observations.

\subsubsection{The Forecasting Performance of Aggregate Balance Statistics}

The forecasting performance of the ZEW survey expectations is detailed in the literature. Breitung and Jagodzinski (2001) and Hüfner and Schröder (2002) find that the ZEW Economic Sentiment Indicator, the survey's aggregate balance statistic of 
output growth expectations for Germany, has good forecasting quality. The forecasting power of inflation and short-term interest rate balances is tested by Nolte and Pohlmeier (2007). The authors discuss a VAR-based forecasting approach and quantification methods that transform the shares of positive and negative assessments from the survey into a quantitative variable, see Carlson and Parkin (1975), and on the regression approach Pesaran (1984). Nolte and Pohlmeier (2007) find that the survey forecasts are unbiased and that their predictive power is comparable to a random walk. Furthermore, they find no support for the hypothesis that experts' forecasting quality depends on subgroups. Ullrich (2008) quantifies the aggregate shares of inflation expectations by means of the Carlson-Parkin method and shows that they are significantly influenced by ECB rhetoric. Her findings suggest that financial market experts keep a sharp eye on ECB communication. These papers have in common that they work with the aggregate balance statistics and do not consider individual heterogeneity.

\subsubsection{Heterogeneous Forecasters}

When exploring the expectation formation process, one should account for the heterogeneity of forecasters, which can be done in several ways. For the Wall Street Journal's panel of economists, Mitchell and Pearce (2007) classify the participants according to subgroups depending on industry or experience. For the same survey panel, Dreger and Stadtmann (2008) show that the heterogeneity in exchange rate forecasts cannot be explained by individual forecasts of macroeconomic variables in the survey context. A more sophisticated way to model forecasters' heterogeneity is proposed by Rangvid, Schmeling, and Schrimpf (2009). They estimate a panel random coefficient model for the stock market expectations of participants in the ZEW financial market survey. In the following, we adopt the random coefficient approach where forecasters' heterogeneity is reflected in the distribution of estimated coefficients. 


\subsection{Individual Interest Rate Forecasts and Taylor Rules}

Most of the relevant literature evaluating the accuracy of forecasts makes no attempt to explain the sources of interest rate forecast errors. In an exception to this trend, Berger, Ehrmann, and Fratzscher (2009) employ a Taylor rule model to investigate interest rate forecast errors of professional ECB policy forecasters. They use quantitative survey data from a Reuters poll in which financial institutions were asked for the expected policy rate. Berger, Ehrmann, and Fratzscher (2009) decompose the interest rate forecast errors $\left(r_{j t}^{e}-r_{t}\right)$ of forecaster $j$ into a systematic $\left(s_{j}\right)$ and an unsystematic $\left(u_{j}\right)$ component. The systematic part depends on the individual Taylor-rule-type forecast equation

$$
r_{j t}^{e}-r_{t}=\hat{\beta}_{j r} r_{t-1}+\sum \hat{\beta}_{j k} x_{k t}+\hat{\beta}_{j \pi} \tilde{\pi}_{j t}-r_{t}+\hat{u}_{j t}=\hat{s}_{j t}+\hat{u}_{j t} .
$$

where $x_{k t}$ are macroeconomic variables and $\tilde{\pi}_{j t}$ is the inflation differential of the country in which the forecaster is located, relative to the Euro zone average. Their empirical results indicate that the systematic component matters for forecast accuracy. In particular, descriptive statistics on average errors suggest that forecasters from financial centers such as Frankfurt or London provide more accurate forecasts. ${ }^{1}$

This paper extends Berger, Ehrmann, and Fratzscher (2009) in two important respects. First, since the ZEW financial market survey not only asks for expected interest rates, but also for expected inflation and output, we can include forwardlooking Taylor rule arguments in each individual interest rate forecast equation, see Section 3. Second, our econometric framework uses a random coefficient model to explicitly model the forecasters' disagreement over appropriate Taylor rule parameters, see Section 4 .

\footnotetext{
${ }^{1}$ In a related work, Berger, Ehrmann, and Fratzscher (2006) show that for the case of anticipating Fed monetary policy decisions, regional differences within the United States play a significant role.
} 


\section{Forecasting Interest Rates with Taylor Rules}

\subsection{The Interest Rate Policy of the Central Bank}

Ever since Taylor's (1993) seminal work, reaction functions specified as Taylor rules, where the central bank determines the key policy rate in response to inflation and output, have been the predominant way of modeling interest rate setting by central banks. Starting with Clarida, Galí, and Gertler (1998), much empirical work confirms that Taylor rules are remarkably adept at describing central bank interest rate decisions (for recent examples, see Jansen and de Haan (2009); Grammig and Kehrle (2008)). In accordance with Berger, Ehrmann, and Fratzscher (2009), we assume that the central bank sets the short-term interest rate in response to contemporaneous output and inflation:

$$
\Delta_{6} i_{t}=\alpha \Delta_{6} \pi_{t}+\beta \Delta_{6} y_{t} .
$$

The Taylor rule is defined in terms of sixth differences $\left(\Delta_{6}\right)$ because the qualitative survey data refer to interest rate changes over six months. From a theoretical point of view, the output gap should be part of the Taylor rule. However, by taking differences, potential output drops out of the equation.

\subsection{Decomposing Individual Forecast Errors}

If the central bank follows a Taylor rule, financial market experts may also use a Taylor rule in formulating their expectations of the central bank decision. Given the survey horizon of six months, an expert $j$ is expected to form his interest rate expectations in $t-6$ for period $t$ according to the following Taylor-rule-type forecast equation

$$
\Delta_{6} i_{j t}^{e}=\alpha_{j} \Delta_{6} \pi_{j t}^{e}+\beta_{j} \Delta_{6} y_{j t}^{e}
$$

According to Equation (2), the interest rate change expected by expert $j$ depends on his expected change in inflation $\Delta_{6} \pi_{j t}^{e}$ and output $\Delta_{6} y_{j t}^{e}$. Note that the expert's 
expectations for inflation and output should be interpreted as a proxy for the forecasts the expert assumes the central bank to have. Unfortunately, these expectations are not asked about in the survey. However, it is likely that experts' inflation and output expectations are influenced by the central bank forecasts, which are regularly published.

The interest rate forecast errors $e_{j t}^{i *}$ are obtained by subtracting the financial market expert's forecast (Equation (2)) from the actually observed interest rate set by the central bank (Equation (1))

$$
\begin{aligned}
e_{j t}^{i *} & =\Delta_{6} i_{t}-\Delta_{6} i_{j t}^{e} \\
& =\alpha \Delta_{6} \pi_{t}+\beta \Delta_{6} y_{t}-\left(\alpha_{j} \Delta_{6} \pi_{j t}^{e}+\beta_{j} \Delta_{6} y_{j t}^{e}\right),
\end{aligned}
$$

where the asterisk in $e_{j t}^{i *}$ is used to be consistent with the latent variable formulation of the econometric model in Section 4. Equation (3) will be estimated in Section 5. To derive the financial market experts' misperception regarding central bank parameters, Equation (3) is rewritten as:

$$
e_{j t}^{i *}=\alpha_{j} e_{j t}^{\pi}+\beta_{j} e_{j t}^{y}+\left(\alpha-\alpha_{j}\right) \Delta_{6} \pi_{t}+\left(\beta-\beta_{j}\right) \Delta_{6} y_{t},
$$

with $e_{j t}^{\pi}=\Delta_{6} \pi_{t}-\Delta_{6} \pi_{j t}^{e}$ and $e_{j t}^{y}=\Delta_{6} y_{t}-\Delta_{6} y_{j t}^{e}$. Equation (4) shows that the overall individual interest rate forecast error can be decomposed into two parts. The first part $\left(\alpha_{j} e_{j t}^{\pi}+\beta_{j} e_{j t}^{y}\right)$ follows from the error a financial market expert makes in forecasting inflation and output. The second component $\left(\left(\alpha-\alpha_{j}\right) \Delta_{6} \pi_{t}+\left(\beta-\beta_{j}\right) \Delta_{6} y_{t}\right)$ is due to the analyst's misperception of how the central bank will react to changes in inflation and output. The central bank can influence both causes of error. First, it can provide the public with macroeconomic projections and, second, it can explain how it reacts to changes in these variables. 


\subsection{Qualitative Interest Rate Forecast Errors}

The answers of the surveyed experts are qualitative, whereas the actual, observed data series is continuous. One way of making the two comparable is to transform the aggregate shares of responses into a quantitative series. ${ }^{2}$ In our application, where the focus is on the individual level, it is more appropriate to transform the realized, quantitative interest rate data into a qualitative variable. To that aim, we transform the sixth differences of the actual interest rate series $\left(\Delta_{6} i_{t}\right)$ into the corresponding qualitative variable $\Delta_{6} i_{j t}^{q}$ as follows:

$$
\Delta_{6} i_{j t}^{q}=\left\{\begin{array}{lll}
1 & \text { if } & \bar{\Delta}_{6} i_{j}<\Delta_{6} i_{t} \\
0 & \text { if } & \underline{\Delta}_{6} i \\
-1 & \text { if } & \Delta_{6} i_{t}<\Delta_{6} i_{t} \leq \underline{\Delta}_{6} i_{j}
\end{array}\right.
$$

where $\underline{\Delta}_{6} i$ and $\bar{\Delta}_{6} i_{j}$ denote individual lower and upper thresholds, which have been surveyed by a special question in the ZEW survey. Within these - partly asymmetricalthresholds, a financial market analyst would continue to say that the underlying macroeconomic variable will not change. Note that individual thresholds imply that the qualitative interest rate variable $\Delta_{6} i_{j t}^{q}$ also depends on the expert. ${ }^{3}$ The qualitative interest rate forecast errors $e_{j t}^{i}$ of expert $j$ are defined as the difference between the qualitative change of the interest rate $\Delta_{6} i_{j t}^{q}$ and the expert's forecast made in period $t-6$ for the change of $i$ six months ahead $\Delta_{6} i_{j t}^{e}$ :

$$
e_{j t}^{i}=\Delta_{6} i_{j t}^{q}-\Delta_{6} i_{j t}^{e} ; \quad e_{j t}^{i} \in\{-2,-1,0,1,2\}
$$

The descriptive statistics on the resulting qualitative interest rate forecast errors, provided in Table 1, show that the mean value of the forecast error $e^{i}$ is close to zero. Moreover, the forecast errors are always between -1 and +1 , implying that the directional forecast has always been correct.

\footnotetext{
${ }^{2}$ Nardo (2003) critically reviews the prevailing quantification methods. She concludes that they do not prove superior to the original, qualitative data.

${ }^{3}$ We use the individual threshold values when they are available and the average thresholds if the individual threshold is not available.
} 
Table 1: Qualitative interest rate forecast errors of experts: Descriptive statistics

\begin{tabular}{llll}
\hline \hline \multicolumn{5}{c}{ Jan 00 - Oct 03 } & Nov 03 - Jul 07 & Aug 07 - Mar 09 \\
\hline \multicolumn{3}{l}{ Interest rate forecast errors } \\
$\mu\left(e^{i}\right)$ & -0.01 & -0.38 & -0.23 \\
$\sigma\left(e^{i}\right)$ & 0.83 & 0.60 & 0.77 \\
$\operatorname{Min}\left(e^{i}\right)$ & -1 & -1 & -1 \\
$\operatorname{Max}\left(e^{i}\right)$ & 1 & 1 & 1 \\
\hline$\#$ obs & 14,183 & 12,758 & 5,132 \\
\hline \hline
\end{tabular}

Notes: Qualitative interest rate forecast errors of the surveyed interest rate expectations versus the 3-month Euribor as constructed in Equation (6).

\section{The Econometric Model}

\subsection{Panel Random Coefficient Ordered Logit Model}

Table 1 shows that the interest rate forecast errors of experts as derived from the ZEW survey are qualitative variables with three ordered outcomes. To explore the determinants of the errors, estimating an ordered logit model is a natural choice. We thus estimate the following econometric model for the latent variable $e_{j t}^{i *}$ for expert $j$, $j=1, \ldots, N$, in month $t, t=0, \ldots, T_{j}:$

$$
e_{j t}^{i *}=\alpha \Delta_{6} \pi_{t}+\beta \Delta_{6} y_{t}-\left(\alpha_{j} \Delta_{6} \pi_{j t}^{e}+\beta_{j} \Delta_{6} y_{j t}^{e}\right)+\varepsilon_{j t} .
$$

The logit model assumes that $\varepsilon_{j t}$ are i.i.d. and follow a logistic distribution $\Phi$. The outcome probabilities $P$ for the observed values $e^{i}$ of the latent variable conditional on the vector of explanatory variables $z_{j t}=\left(1, \Delta_{6} \pi_{t}, \Delta_{6} y_{t}, \Delta_{6} \pi_{j t}^{e}, \Delta_{6} y_{j t}^{e}\right)$ are defined as follows, see Wooldridge (2001):

$$
\begin{aligned}
& P\left(e_{j t}^{i}=-1 \mid z_{j t}\right)=P\left(e_{j t}^{i *} \leq 0 \mid z_{j t}\right)=\Phi\left(-z_{j t}^{\prime} \delta_{j}\right) \\
& P\left(e_{j t}^{i}=0 \mid z_{j t}\right)=P\left(0<e_{j t}^{i *} \leq \varsigma_{1} \mid z_{j t}\right)=\Phi\left(\varsigma_{1}-z_{j t}^{\prime} \delta_{j}\right)-\Phi\left(-z_{j t}^{\prime} \delta_{j}\right) \\
& P\left(e_{j t}^{i}=1 \mid z_{j t}\right)=P\left(\varsigma_{1}<e_{j t}^{i *}\right)=1-\Phi\left(\varsigma_{1}-z_{j t}^{\prime} \delta_{j}\right)
\end{aligned}
$$

where $\varsigma_{1}$ is a threshold parameter for the probability categories. 
To measure dispersion of the forecasting models across the financial market experts, we estimate a random coefficient model according to Swamy (1970). Under this approach, we incorporate cross-sectional heterogeneity of the assessments for inflation and output. Cross-sectional heterogeneity in Equation (7) is introduced via the random coefficients $\alpha_{j}$ and $\beta_{j}$. Specifically, the random coefficients are specified as follows:

$$
\left(\begin{array}{c}
\alpha_{j} \\
\beta_{j}
\end{array}\right)=\left(\begin{array}{c}
\bar{\alpha} \\
\bar{\beta}
\end{array}\right)+\left(\begin{array}{cc}
\sigma_{\alpha} & 0 \\
0 & \sigma_{\beta}
\end{array}\right)\left(\begin{array}{l}
\xi_{j}^{\alpha} \\
\xi_{j}^{\beta}
\end{array}\right)
$$

with $\xi_{j}^{\alpha}, \xi_{j}^{\beta} \sim \mathcal{N}(0,1) . \quad \sigma_{\alpha}$ and $\sigma_{\beta}$ measure the dispersion of the estimated model coefficients across the financial market experts. Systematic misperception of monetary policy is present if the mean values $\bar{\alpha}$ and $\bar{\beta}$ deviate significantly from $\alpha$ and $\beta$, the central bank parameters.

\subsection{The ECB's Clarification of the Monetary Policy Strategy}

Given the economic interpretation of the mean and dispersion parameters of the random coefficient model for the experts' interest rate forecast errors, we now test whether these parameters responded to ECB communication or to the financial market crisis. The ECB made two announcements with respect to monetary policy strategy. In the first, in October 1998, ${ }^{4}$ the ECB declared that its strategy would consist of three elements. Price stability, the primary objective, would be achieved with inflation rates of below $2 \%$. Money would play a prominent role in assessing the risks to price stability and the outlook for price stability would be based on a broad assessment. In May $2003,{ }^{5}$ the ECB released the second statement on monetary policy strategy. This communication mainly confirms ECB's definition of price stability, but specifies more clearly that inflation rates of less than, but close to, $2 \%$ are desirable. At the same time, by classifying money as a means for cross-checking the risks to price stability, the role of money in its short-term interest rate policy was de-emphasized.

\footnotetext{
${ }^{4}$ See ECB press release "A stability-oriented monetary policy strategy for the ESCB" on October 13, 1998.

${ }^{5}$ See ECB press release "The ECB's monetary policy" on May 8, 2003.
} 
The ECB has repeatedly emphasized that the May 2003 announcement should be viewed as a clarification and should not be misinterpreted as a change in its monetary policy strategy, see, e.g., Berger, de Haan, and Sturm (2006). Accordingly, the experts' understanding of monetary policy should have become clearer due to improved central bank communication. In terms of the econometric model, the mean coefficients should be closer to the central bank coefficients after the May announcement and the dispersion parameters should have decreased. Because the ECB explicitly "confirmed" its strategy and has since emphasized that the announcement was not a change in policy, in our estimation we assume that the central bank parameters are constant over time. Similarly, we assume that ECB's monetary policy strategy did not change during the financial market crisis. In fact, the ECB has not published any statements to the contrary. Also, during the financial market crisis, the ECB motivated interest rate decreases with diminished inflation risks.

\section{Why Financial Experts Misperceive the ECB's Interest Rate Decisions: Empirical Results}

Table 2 presents the results from a panel random coefficient ordered logit estimation. The upper part of the table presents the nonrandom coefficients. We interacted the experts' Taylor rule parameters with three dummy variables, $D^{I}, D^{I I}, D^{I I I}$, respectively. Thus, we can infer how the ECB communication in 2003 or the financial crisis influenced the experts' Taylor rule parameters. The lower part of Table 2 sets forth the random coefficients of the financial market experts, which are shown in terms of the parameter means across experts $(\bar{\alpha}, \bar{\beta})$ and the dispersion measures $\left(\sigma_{\alpha}, \sigma_{\beta}\right)$.

The positive central bank parameter $\alpha$ for inflation indicates that the probability of tighter monetary policy increases with inflation. This result is in line with the ECB's monetary policy strategy, which clearly emphasizes price stability as its primary objective. In contrast, the sign of the estimated output parameter $\beta$ of the central bank 
Table 3: Wald tests on Taylor rule parameter equality

\begin{tabular}{llll}
\hline \hline $\mathcal{H}_{0}: \mathcal{D}=0$ & & & p-value \\
\hline Misperception of ECB policy & Expert - ECB coefficient) & \\
Inflation & $\bar{\alpha}^{I}-\alpha$ & 0.41 & 0.00 \\
& $\bar{\alpha}^{I I}-\alpha$ & $=0.28$ & 0.00 \\
$\bar{\alpha}^{I I}-\alpha$ & $=0.14$ & 0.00 \\
$\bar{\beta}^{I}-\beta$ & $=-0.25$ & 0.00 \\
$\bar{\beta}^{I I}-\beta$ & $=-0.29$ & 0.00 \\
$\bar{\beta}^{I I I}-\beta$ & $=0.73$ & 0.00 \\
\hline Impact of ECB communication & in 2003 & 0.00 \\
$\bar{\alpha}^{I I}-\bar{\alpha}^{I}$ & $=-0.13$ & 0.21 \\
$\bar{\beta}^{I I}-\bar{\beta}^{I}$ & $=-0.04$ & \\
\hline Change in expert's coefficient due to crisis & 0.00 \\
$\bar{\alpha}^{I I I}-\bar{\alpha}^{I I}$ & $=-0.14$ & 0.02 \\
$\bar{\beta}^{I I I}-\bar{\beta}^{I I}$ & $=1.02$ & \\
\hline \hline
\end{tabular}

Notes: Wald statistics refer to the estimated coefficients in Table 2.

corresponding Wald test statistics, the experts significantly overestimated the central bank's inflation parameter. The ECB's clarification in 2003 induced a significant change in the analysts' perception of ECB policy such that their estimated coefficient is now closer to the ECB's coefficient $\alpha$. Since the financial market crisis, the experts' inflation parameter has continued to decrease significantly. This finding implies that in this period the experts seemed to see less need for the ECB to fight inflation given the severe economic environment. Whereas $(\bar{\alpha}-\alpha)$ measures the accuracy of the financial analysts' expectations regarding the "true" value $\alpha, \sigma_{\alpha}$ measures their disagreement. Table 2 shows that disagreement with respect to the inflation parameter is relatively moderate and hardly changes during the entire sample period. In particular, the experts' disagreement over the ECB's reaction to inflation does not become stronger during the financial crisis.

With respect to output growth, the estimated parameters of the financial market 
experts are negatively signed until July 2007 and positively signed since August 2007 (see Table 2). The latter finding suggests that financial analysts expected the ECB to be more supportive of output growth. Indeed, the ECB decreased interest rates from 4\% in August 2007 to $1.5 \%$ in March 2009. The ECB motivated monetary policy easing primarily with declining inflationary risks. Table 3 shows that the experts' assessment of the weight of output growth deviated significantly from the central bank's weight in all subperiods. The strongest misperception regarding the ECB's reaction to output growth appears during the period of the financial crisis. Until July 2007 , disagreement about the output parameter $\left(\sigma_{\beta}\right)$ was similar in size to the dispersion parameter for inflation, but it has increased considerably since the financial crisis, suggesting a stronger disagreement over the ECB's reaction to output.

The mean squared error $(M S E)$ in the third panel of Table 2 represents a summary impreciseness measure for the experts' misperception of the ECB's interest rate policy. For example, $M S E_{\alpha}=(\bar{\alpha}-\alpha)^{2}+\sigma_{\alpha}^{2}$ accounts in each subperiod for the deviation of the experts' average inflation parameter $\bar{\alpha}$ from the central bank parameter $\alpha$ and the dispersion $\sigma_{\alpha}$. Table 2 shows that for inflation, this measure decreases over time, whereas for the output parameter, the mean squared error is highest since the outbreak of the financial crisis.

\section{Conclusions}

There is a growing consensus among economists and central bankers that expectations management by the central bank is crucial to effective monetary policy. Because households and firms are forward looking, central banks affect the economy as much through their influence on expectations as through any direct effect of their policy instruments. Therefore, central banks are increasingly interested in how markets form expectations about future interest rate decisions. If market participants are confused about the goals and rules of monetary policy, analyzing expectations data 
should reveal that individual forecasters systematically misunderstand future interest rate decisions.

This paper investigated why financial market experts misperceive the interest rate policy of the European Central Bank (ECB). Assuming a Taylor-rule-type reaction function of the ECB, we employed qualitative survey data on expectations about the future interest rate, inflation, and output to discover the sources of forecast error. To that end, we decomposed the individual interest rate forecast errors of financial experts into two components. The first part of the error occurs because forecasters are wrong about future inflation and output, even if they correctly assess the monetary policy strategy. The second part of the error, however, occurs because markets are confused about monetary policy, i.e., there is a lack of understanding as to how the central bank sets interest rates in response to inflation and output. In the case of this second type of error, communication ought to be improved because markets will misperceive future monetary policy decisions even under perfect information about the economic outlook. We estimated the empirical relevance of both components for interest rate forecast errors using a panel random coefficient model in order to explicitly account for the heterogeneity and disagreement of forecasters.

Our empirical results reveal that financial experts have systematically misunderstood the ECB's interest rate rule. However, although experts tend to overestimate the impact of inflation on future interest rates, their perceptions of monetary policy have been far more accurate since the ECB clarified its monetary policy strategy in May 2003. Due to this improved communication, we find that there has been less disagreement over the ECB's response to inflation during the financial crisis. 


\section{References}

Berger, H., J. de HaAn, and J.-E. Sturm (2006): "Does money matter in the ECB strategy?," CESifo Working Paper, No. 1652.

Berger, H., M. Ehrmann, and M. Fratzscher (2006): "Geography or skills: What explains Fed watchers' forecast accuracy of US monetary policy?," $E C B$ Working Paper, No. 695.

(2009): "Forecasting ECB monetary policy: Accuracy is a matter of geography," European Economic Review, 53(8), 1028-1041.

Blinder, A. S., M. Ehrmann, M. Fratzscher, J. DeHaan, and D.-J. Jansen (2008): "Central bank communication and monetary policy: A survey of theory and evidence," Journal of Economic Literature, 46(4), 910-945.

Breitung, J., AND D. JAGOdZinski (2001): "Prognoseeigenschaften alternativer Indikatoren für die Konjunkturentwicklung in Deutschland," Konjunkturpolitik, 47, $292-314$.

Capistrán, C., and M. Ramos-Francia (2010): "Does inflation targeting affect the dispersion of inflation expectations?," Journal of Money, Credit and Banking, 42(1), 113-134.

Carlson, J. A., And M. Parkin (1975): "Inflation expectations," Economica, 42(166), 123-138.

Clarida, R., J. Galí, and M. Gertler (1998): "Monetary policy rules in practice: Some international evidence," European Economic Review, 42, 1033-1067.

Dreger, C., and G. Stadtmann (2008): "What drives heterogeneity in foreign exchange rate expectations: Insights from a new survey," International Journal of Finance and Economics, 13, 360-367. 
Ehrmann, M., S. Eijffinger, and M. Fratzscher (2010): "The role of central bank transpareny for guiding private sector forecasts," ECB Working Paper, No. 1146.

Ehrmann, M., And M. Fratzscher (2007): "Transparency, disclosure and the Federal Reserve," International Journal of Central Banking, 3(1), 179-225.

Grammig, J., And K. Kehrle (2008): "A new marked point process model for the federal funds rate target: Methodology and forecast evaluation," Journal of Economic Dynamics \& Control, 32, 2370-2396.

HÜFner, F., AND M. Schröder (2002): "Prognosegehalt von ifoGeschäftserwartungen und ZEW-Konjunkturerwartungen: Ein ökonometrischer Vergleich," Jahrbücher für Nationalökonomie und Statistik, 222(3), 316-336.

JAnsen, D.-J., AND J. DE HAAN (2009): "Has ECB communication been helpful in predicting interest rate decisions? An evaluation of the early years of the Economic and Monetary Union," Applied Economics, 41, 1995-2003.

Lange, J., B. Sack, and W. Whitesell (2003): "Anticipations of monetary policy in financial markets," Journal of Money, Credit and Banking, 35(6), Part 1, 889909.

Mitchell, K., And D. K. Pearce (2007): "Professional forecasts of interest rates and exchange rates: Evidence from the Wall Street Journal's panel of economists," Journal of Macroeconomics, 29, 840-854.

NARDO, M. (2003): "The quantification of qualitative survey data: A critical assessment," Journal of Economic Surveys, 17(5), 645-668.

Nolte, I., And W. Pohlmeier (2007): "Using forecasts of forecasters to forecast," International Journal of Forecasting, 23, 15-28. 
Pesaran, M. H. (1984): "Expectation formation and macroeconomic modelling," in Contemporary Macroeconomic Modelling, ed. by P. Malgrange, and P. Muet, pp. 27-55. Oxford: Blackwell.

Rangvid, J., M. Schmeling, and A. Schrimpf (2009): "Higher-order beliefs among professional stock market forecasters: Some first empirical tests," $Z E W$ Discussion Paper, No. 09-042.

Sturm, J.-E., AND J. DE HAAN (2009): "Does central bank communication really lead to better forecasts of policy decisions? New evidence based on a Taylor rule model for the ECB," CESifo Working Paper, No. 2760.

Swamy, P. A. V. B. (1970): "Efficient inference in a random coefficient regression model," Econometrica, 38(2), 311-323.

Swanson, E. T. (2006): "Have increases in Federal Reserve transparency improved private sector interest rate forecast?," Journal of Money, Credit and Banking, 38(3), $791-819$.

TAYlor, J. B. (1993): "Discretion versus policy rules in practice," CarnegieRochester Conference Series on Public Policy, 39, 195-214.

UlLRICH, K. (2008): "Inflation expectations of experts and ECB communication," North American Journal of Economics and Finance, 19, 93-108.

WoOlDRIDGE, J. M. (2001): "Econometric analysis of cross section and panel data," The MIT Press. 


\section{A Appendix}

\section{A.1 More Details about the Data}

Table 4: Survey expectations of inflation and output: Descriptive statistics

\begin{tabular}{llll}
\hline \hline \multicolumn{5}{c}{ Jan 00 - Oct 03 } & Nov 03 - Jul 07 & Aug 07 - Mar 09 \\
\hline \multicolumn{3}{l}{ Expected 6-month change in inflation } \\
$\mu\left(\pi_{j t}^{e}\right)$ & -0.12 & 0.21 & -0.08 \\
$\sigma\left(\pi_{j t}^{e}\right)$ & 0.74 & 0.65 & 0.83 \\
\hline \multicolumn{5}{l}{ Expected 6-month change in output } \\
$\mu\left(y_{j t}^{e}\right)$ & 0.40 & 0.34 & -0.39 \\
$\sigma\left(y_{j t}^{e}\right)$ & 0.65 & 0.61 & 0.63 \\
\hline \hline
\end{tabular}

Notes: The table shows descriptive statistics of the individual survey expectations with respect to output and inflation. The data are qualitative with possible discrete values $\{-1,0,1\}$.

Figure 1: Euro zone time series data

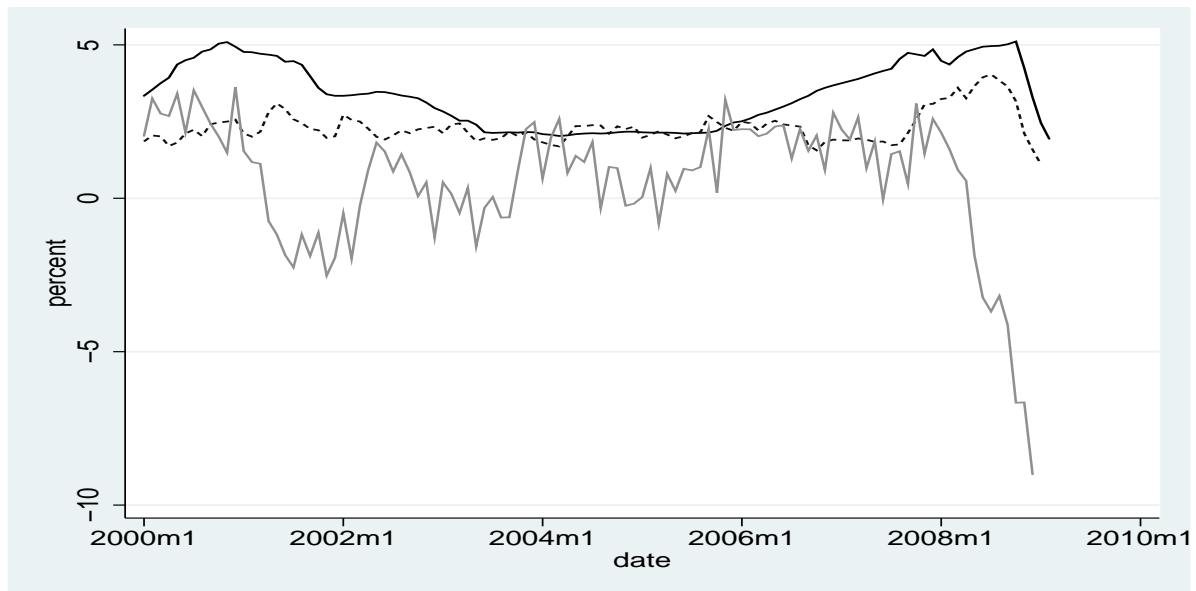

Notes: 3-month Euribor (black line), HICP inflation (dashed line) and six month growth rate of industrial production (grey line) in the euro zone. 
Table 5: Description of Variables

\begin{tabular}{ll}
\hline \hline Variable & Definition \\
\hline$\Delta_{6} i_{t}$ & Change in 3-month Euribor from $t-6$ to $t$ \\
$\Delta_{6} \pi_{t}$ & Change in annual HICP inflation from $t-6$ to $t, \mathrm{SA}$ \\
$\Delta_{6} y_{t}$ & Growth of industrial production from $t-6$ to $t, \mathrm{SA}$ \\
\hline Survey expectations & Survey question \\
\hline$\Delta_{6} i_{j t}^{e}$ & "In the medium-term (6 months) the short-term \\
& interest rates (3-month-Interbank rate) will \\
& $\ldots$ increase / no change / decrease" \\
$\Delta_{6} \pi_{j t}^{e}$ & "In the medium-term (6 months) the macroeconomic annual \\
$\Delta_{6} y_{j t}^{e}$ & inflation rate will ... increase / no change / decrease" \\
& "In the medium-term (6 months) the overall macroeconomic \\
\hline Definition of subperiods & situation will ... improve / no change / worsen" \\
\hline$D^{I}$ & January 2000 to October 2003 \\
$D^{I I}$ & November 2003 to July 2007 \\
$D^{I I I}$ & August 2007 to March 2009 \\
\hline \hline
\end{tabular}

Notes: All data refer to the euro zone. Data sources: ECB, Thomson Financial Datastream, ZEW. 